\title{
Work-Family Conflict: A Review Of Antecedents And Outcomes
}

Katarina Katja Mihelič, University of Ljubljana, Slovenia Metka Tekavčič, University of Ljubljana, Slovenia

\begin{abstract}
This paper discusses the work-family conflict that forms the central construct of the work-family literature, and is defined as the experience of mutually incompatible pressures that stem from work and family domains. Juggling myriad responsibilities within the areas of work and family two of the most important life domains for most adults - has become increasingly difficult. Consequently, the level of experienced conflict has been rising steadily in the last three decades and has a detrimental effect on the individual, family, organizations, and society at large.

On the basis of construct definition, the purpose of this paper is to provide a synthesis of the antecedents and outcomes of the work-family conflict. The authors first analyze two categories of antecedents - individual differences and job/family characteristics. Furthermore, outcomes are classified as variables related to well-being, attitudes, and behaviors. By having a clearer understanding of what causes conflict between work and family roles and by being aware of the detrimental effects that conflict has on individuals and organizations, HR professionals, managers, and representatives of other institutions can work together toward developing initiatives for the better integration of work and family roles.
\end{abstract}

Keywords: Work-Family Conflict; Review; Empirical Studies; Antecedents; Individual Outcomes

\section{INTRODUCTION}

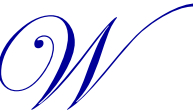

ork and family are the two most important life domains for adults (Casper et al., 2011; Michel et al., 2011). Technological advances have changed the everyday life of the individual for the better, as well as for the worse (Milliken \& Dunn-Jensen, 2005), with the latter mostly due to a further blurring of domain boundaries - in particular, the family's (Dugan et al., 2012). These changes in societies around the globe have led to an increase in the perception of work-family conflict (Duxbury \& Higgins, 2002) - the most studied construct in work-family literature (Eby et al., 2005; Byron, 2005) that arises when an individual is faced with conflicting and simultaneous demands that stem from either his work or family role. The pressures of multiple roles that women and men experience suggest that the conflict between roles within an adult individual is unavoidable and the consequences for the individual and organization are imminent.

The dominant construct in the work-family literature is the work-family conflict (Allen et al., 2000; Byron, 2005), defined as "a form of inter-role conflict in which the role pressures from the work and family domains are mutually incompatible in some respect" (Greenhaus \& Beutell, 1985, str. 77). Even though negative spillover may occur in both directions, work-family conflict is far more prevalent than family-work conflict (Aryee et al., 1999; Netemeyer et al., 1996; Bellavia \& Frone, 2005) due to the fact that work boundaries are less permeable than family boundaries (Dugan et al., 2012).

The purpose of this paper is to investigate the nature of the construct of work-family conflict, and to provide a review of its antecedents and outcomes by including recent research findings. The rationale for focusing on the conflict construct lies in the fact that organizations, which understand causes and consequences of workfamily conflict, can actively engage in activities aimed at reducing work-family conflict. Research shows that workfamily initiatives, particularly in the form of schedule controls, can reduce work-family conflict, buffer the negative 
effects of long work hours (Kelly et al., 2011; Carlson et al., 2011), and improve firms' performances. We include research findings published in the field of organizational behavior, management, industrial/occupational psychology, sociology, and family studies.

\section{ANTECEDENTS OF WORK-FAMILY CONFLICT}

\subsection{Individual Differences}

Most research on predictors of work-family conflict focuses on the situational variables, be it in the work domain (e.g., work hours, job characteristics, and company culture) or family domain (e.g., family structure and partner support). The role of dispositional factors (i.e., personality characteristics) (Carlson, 1999, Baltes et al., 2011) in understanding the relationship between work and non-work has been, until recently, neglected. The rationale for inclusion of personality variables in work-family literature lies in the belief that "personality traits which enable an employee to use his or her time more efficiently, to engage in roles with more energy, to perceive less stress, or to adopt coping mechanisms that reduce stress, should be related to less conflict" (Wayne et al., 2004, p. 110).

The theory of personality based on five dimensions has been successfully integrated in work-family literature. While neuroticism has been hypothesized as a "risk factor" that predisposes an individual to encounter work-family conflict, agreeableness, extraversion, and conscientiousness are perceived as "resource factors" preventing one from experiencing conflict. Finally, it is believed that openness to experience is neither a risk nor a resource factor in its relation to conflict (Rantanen et al., 2005). Using a random U.S. sample, Wayne et al. examined the influence of the Big Five dimensions on work-family conflict and confirmed that conscientiousness and agreeableness were significant and negative predictors (with $\beta$ coefficients -0.15 and -0.16 , respectively), whereas neuroticism was found to be a positive predictor $(\beta=0.38)$ (Wayne et al., 2004). A negative relationship between agreeableness and time-based work-family conflict was also found in another study (Bruck \& Allen, 2003). Whereas emotional stability was found to have a negative effect on work-family conflict (Baltes et al., 2011), a higher level of neuroticism was associated with more work-family conflict for both men and women in a U.S. sample as well (Grzywacz \& Marks, 2000). In terms of conflict sub-dimensions, neuroticism was positively related to strain-based and time-based work-family conflict (Andreassi, 2011). Extraversion and openness for experience has no significant relationship to either form of conflict in two studies (Wayne et al., 2004; Bruck \& Allen, 2003). However, Grzywacz and Marks (2000) did find that extraversion is positively related to conflict. In a study of Finnish employees (the majority of them lower white-collar workers) that aimed to provide knowledge about the role of personality in work-family conflict over a longer period of time, the authors found a positive relationship between neuroticism and conflict for both men and women (results confirm previous findings) and no relationship regarding openness to experience (in line with hypothesis and other findings). Surprisingly, extraversion, agreeableness, and conscientiousness had no influence on conflict either.

Negative affect refers to the tendency to experience aversive emotional and mood states. Those people that score high in negative affectivity are, over time, more likely to report discomfort and dissatisfaction regardless of the situation (Carlson, 1999). Negative affect is positively related to work-family conflict (Carlson, 1999; Stoeva et al., 2002) One study found that it was related solely to strain-based work-family conflict (Bruck \& Allen, 2003), whereas the study by Carlson (1999) showed that it is positively related to all three forms of conflict and plays the strongest role in connection with strain-based conflict. Recent analysis found negative affect to be a strong predictor of conflict $(\beta=0.54)$. Authors additionally found that respondents with higher negative affect experience lower levels of job and family satisfaction (Michel \& Clark, 2009). In a meta-analytic study (Michel et al., 2011), authors confirmed that negative affectivity had a moderate relationship with work-family conflict $(\rho=0.38)$.

Another variable that has been integrated in the work-family literature is Type A personality disposition, which characterizes individuals as persistent, impatient, ambitious, and preoccupied. They are highly involved in work, thus working long hours and investing a lot of energy into tasks with the aim of exceeding expectations. People of such natures are more prone to experiencing difficulties in managing multiple roles. Carlson examined the connections in more detail and predicted that Type A personalities have a positive relationship with time-based and strain-based conflict and not with behavior-based conflict. The findings were contrary to expectations. Type A had a 
negative and significant relation to behavior-based conflict only. Carlson assumed that such results are due to use of a global measure, which might not have adequately captured different aspects of Type A behavior (Carlson, 1999). Bruck and Allen (2003) therefore approached the investigation by considering two facets of Type A behavior achievement strivings (individuals exhibiting such behavior are considered to be hard working) and impatienceirritability (individuals are characterized as being prone to anger). They found neither of the Type A facets to be significantly related to work-family conflict, even though the impatience-irritability facet was correlated with overall work-family conflict.

In terms of other individual differences, trait emotional intelligence and one of its dimensions - self-control - was found to be associated with work-family conflict (Biggart et al., 2010) as was maladaptive perfectionism (Beauregard, 2006). Furthermore, an internal locus of control (extent to which individuals believe that they are the creators of their actions and that consequences of their acts are mainly dependent on themselves) also exhibited a negative relationship with work-family conflict in single studies (Noor, 2002) and meta-analysis $(\rho=-0.21)$ (Michel et al., 2011). Studies that included two other personality characteristics - self-efficacy and self-esteem - found that self-efficacy correlates negatively with work-family conflict (Cinamon, 2006) and self-esteem has a significant negative impact $(\beta=-0.13)$ (Beauregard, 2006). A longitudinal study from eight different occupations confirmed the same relationship between performance-based self-esteem and work-family conflict (Innstrand et al., 2010a).

Finally, authors in one study evaluated how a particular attachment style affects work-family conflict among 481 U.S. employees occupying academic and non-academic positions. They found that people with preoccupied attachment styles (those characterized by a negative image of self and a positive image of others when forming relationships) report more work-family conflict. This is in line with theoretical assumptions that a negative image of self is associated with high interpersonal dependency and low global self-esteem (Sumer \& Knight, 2001). This study is insightful due to the fact that they shift focus from defining a relationship to researching whether people experience the relationship between work and family in different ways.

\subsection{Job and Family Characteristics}

Research shows that work, rather than family characteristics, have the strongest correlation with workfamily conflict (Frone et al., 1992). Thus, the major part of this subsection is devoted to work variables, notwithstanding the last paragraph that lists some significant influences caused by family variables. Job stressors and job involvement are positively related to the frequency of work-family conflict. Job requirements, particularly those related to scheduling (e.g., working in shifts, overtime, weekend, and evening work), impose on one's personal time and thereby create imbalance in the role time allocation. Job stress $(\rho=0.48)$ and schedule flexibility $(\rho=-$ 0.30 ) are those work-related antecedents that have been found to have the strongest relationships with work-family interference in a meta-analytic study (Byron, 2005). Frequent business travel also increases the perceived time-based conflict. Grzywacz and Marks (2000) found job pressure to be one of the crucial predictors of conflict perception. Namely, in contrast to men and women in the highest tertile of work pressure, being in the lowest tertile is related to almost one standard deviation reduction in the work-family conflict. Studies show that time pressure, workload pressure, role conflict, and ambiguity have a positive relationship with work-family conflict (Bellavia \& Frone, 2005; Voydanoff, 2007). Furthermore, psychological involvement shows positive associations, as does work overload (Geurts et al., 1999).

Lower levels of support at work cause more negative spillover from work to family (Grzywacz \& Marks, 2000). The support of the supervisor is negatively associated with work-family interference (Blanch \& Aluja, 2012b) and is related to perceptions of greater organizational work-life support (Valcour et al., 2011). According to Michel et al. (2011), social support within work domain is negatively related to work-family conflict. Specifically, organizational support has a moderate negative relationship with work-family conflict $(\rho=-0.30)$, whereas supervisor support $(\rho=-0.22)$ and coworker support $(\rho=-0.25)$ show slightly weaker relationships. Managerial support also has a significant negative relationship (Beauregard, 2006). On the other hand, abusive supervision is directly related to work-family conflict, as well as indirectly related through emotional labor and burnout (Carlson et al., 2012). 
Working time is another organizational antecedent of work-family conflict. Researchers follow the proposition that the most crucial influence of professional work on family life is represented in the amount of time that an individual allocates to his/her job activities and professional career. Most empirical studies confirm that a longer working time increases the perceived work-family conflict (Beauregard, 2006; Byron, 2005; Grzywacz \& Marks, 2000) as does work overload (Bolino \& Turnley, 2005) and non-standard working time (Carlson et al., 2011). The increase in working hours, high job involvement, and job stress deepens the spillover of work into family and thus contributes to lower psychological well-being (Ng \& Feldman, 2008; Byron, 2005; Milliken \& DunnJensen, 2005). Grzywacz and Marks (2000), for example, found that women who reported working less than twenty hours per week reported less conflict, whereas working 45 hours per week or more causes more conflict for both women and men. Additionally, not only objective working time, but also the stress that one experiences when not having sufficient time to fulfill all obligations, causes work-family conflict. In turn, the perceived time pressure serves as the predictor of the amount of time an individual allocates to each domain (Dugan et al., 2012).

Organizational culture is also important in predicting work-family conflict as it serves as a signal of the acceptability of one's personal choices regarding family and work life. If the employees view their employing organization as family-supportive, they tend to experience less work-family conflict (Lapierre et al., 2008). Research indicates that a positive work-family culture has a much stronger impact in work-family conflict experience than family-friendly policies (Premeaux et al., 2007). A study of Swedish fathers found that if they perceived the organization as family-friendly, they were better able to combine work and family and experience less conflict (Allard et al., 2011). Another study found that a hindrance organizational culture increases work-family conflict and leads to burnout, whereas a supportive culture leads to less conflict and more engagement (Peeters et al., 2009). The fact that people have less time than they need to do everything their job requires results in a decreased amount of available family time as working time creeps into non-working time. Milliken coined the term work creep to describe a situation in which work creeps and intrudes into personal and family time and gradually claims it. In Milliken's study, 55\% of respondents confirm that they face "work creep" on a daily basis and attribute this to technological developments that enable and ease tele-work. Ninety-five percent of surveyed employees feel time pressure and 65\% feel that today they work longer compared to five years ago (Milliken, 2004).

Different aspects of family structure also influence the perception of conflict between work and family, even though variables related to family primarily serve as predictors of family-work conflict rather than work-family conflict (Byron, 2005; Frone et al., 1992). Nevertheless, there is evidence that family characteristics affect negative spillover from work to family as well. Parents report more conflict than non-parents (Mauno et al., 2011; Byron, 2005). Number of children living in the household or their presence are, for example, positively associated with conflict (Beauregard, 2006; Netemeyer et al., 1996; Kinnunen \& Mauno, 1998), whereas the age of children has a negative influence (Winslow, 2005). A Norwegian study found that conflicts between the work and family domains are more intense among single parents and couples with children than those without children (Innstrand et al., 2010b). The weighted mean average (meta-analytic) correlation between the number of children and work-family interference differs for males and females, with 0.15 for males and 0.02 for females, respectively (Byron, 2005). Respondents in Spain that are married with children experience greater work-family conflict than single respondents (de Luis Carnicer et al., 2004). Married respondents reported higher conflict than non-married counterparts (Grzywacz \& Marks, 2000), as did parents compared to non-parents (Grzywacz et al., 2002; Winslow, 2005). Age, marriage, and fewer children were variables related to lower levels of stress in the conservation of resources model (Grandey \& Cropanzano, 1999). Family support and spousal support were both found to decrease the level of workfamily conflict (Michel et al., 2011; Blanch \& Aluja, 2012a). Specifically, men who experience less affectual support from family members perceive more negative spillover from work to family (Grzywacz \& Marks, 2000). Being criticized or burdened by family members causes more conflict for women (and not for men) (Grzywacz \& Marks, 2000). Instrumental spousal support decreases all forms of work-family conflict (time-, strain- and behaviorbased) (Halbesleben et al., 2012).

\section{OUTCOMES OF WORK-FAMILY CONFLICT}

\subsection{Individual Well-Being}

Those work-family linkages that are perceived as conflictual bring dysfunctional consequences for individual's physical and psychological well-being. There is growing evidence that supports the notion that work- 
family conflict leads to poor physical health (Frone, 2000; Carlson et al., 2011), poor perceived health (Mauno et al., 2011), and depressive behavior (based on self-evaluation) (Grandey \& Cropanzano, 1999; Bellavia \& Frone, 2005; Allen et al., 2000). With regard to physical health, Allen et al. (2000) calculated a weighted mean correlation of 0.29 between physical symptoms or somatic complaints and work-family conflict. Work-family conflict, as Bellavia and Frone (2005) report, negatively affects physical and mental health. It causes physical health problems like hypertension (Frone et al., 1997), obesity (Grzywacz, 2000), high cholesterol levels, lower physical stamina (van Steenbergen \& Ellemers, 2009) and behaviors like overeating, skipping meals, and devoting less time and energy to exercise. Other authors report the following symptoms: problems with sleep, headaches, fatigue, chest pains, and alcohol abuse (Geurts et al., 1999; Frone et al., 1997).

Consistent research findings prove that increased work-family conflict brings negative psychological consequences as well. The average weighted correlation between conflict and general psychological strain is 0.29 , whereas the correlation with depression is 0.32 (Allen et al., 2000). A strong and positive relationship was also found with emotional exhaustion (Halbesleben et al., 2012). Frone (2000) tested the links with specific types of psychiatric disorders - mood (depressive and manic episodes), anxiety (agoraphobia, social phobia, posttraumatic stress), psychoactive substance use (alcohol/drug abuse/dependence) and others (conduct, antisocial personality disorder). He found that people who experience work-family conflict often were 3.13 times more likely to have a mood disorder, 2.46 times more likely to have an anxiety disorder and 1.99 times more likely to have a substance dependence disorder in comparison with those who do not experience work-family conflict (Frone, 2000).

One of the pressing psychological consequences is burnout that represents "energy leakage," a consequence of a long-term stress at work and has been related to conflict (Kinnunen \& Mauno, 1998; Blanch \& Aluja, 2012b; Peeters et al., 2009). A meta-analytic study shows that the correlation between the cause and effect is relatively strong (average weighted $\rho=0.42$ ) (Allen et al., 2000). In a study of Dutch medical workers, burnout was measured with two facets - emotional exhaustion (a sense of emptiness, lack of emotional resources) and depersonalization (a mood in which negative and cynical attitudes dominate). The correlations with work-family conflict were 0.51 and 0.32 , respectively (Geurts et al., 1999).

\subsection{Attitudinal Outcomes}

Various studies suggest that work-family conflict brings costly and detrimental consequences for the organization (Eby et al., 2005). The negative spillover between work and family first affects the reformation of attitudes, related to work and organization. Next, changes in relationships among family members emerge and attitudes towards family change. Many studies investigated the impact of conflict on job satisfaction and found a negative relationship (Netemeyer et al., 1996; Bruck et al., 2002) using measures of global, as well as composite, job satisfaction. The usage of the latter generally showed a stronger relationship. Netemeyer et al. (1996) confirmed this negative relation in three samples with correlational coefficients amounting to $-0.36,-0.21$, and -0.27 .

In their meta-analysis, Kossek and Ozeki (1998) report the average weighted mean correlation to be -0.23 and a similar strength of relationship is found in Bruck's (2002) meta-analysis $(\rho=-0.28)$, as well as Allen et al.'s (2000) $(\rho=-0.24)$ review. Bruck et al. (2002) found that behavior-based work-family conflict added unique variance to the prediction of global and composite job satisfaction, above time- and strain-based conflict. Significant relationships between conflict and satisfaction at work have been found across different occupations (Netemeyer et al., 1996; Thomas \& Ganster, 1995). Increasing work-family conflict leads to lower job satisfaction and thereby lowers the quality of working life (Netemeyer et al., 1996). Authors in one longitudinal study, for example, found that conflict impacts subjective well-being in a negative way $(\beta=-0.29)$ in the first round of surveys, as well as in the second round, after six months $(\beta=-0.11)$. Conflict has been found to be a significant longitudinal predictor of well-being (Grant-Vallone \& Donaldson, 2001).

Higher levels of conflict lead to a lower organizational commitment (Netemeyer et al., 1996; Allen et al., 2000; Kossek \& Ozeki, 1998). A study of doctors and nurses found that the more committed they were, the more work-family conflict they experienced (Benligiray \& Sönmez, 2012). In a study of Brazilian employees, workfamily conflict was related to higher continuance commitment (Casper et al., 2011). In their meta-analysis, Kossek and Ozeki report that the average mean correlation is -0.23 (Kossek \& Ozeki, 1998) and a similar result, -0.24 , is 
reported by Allen et al. (2000), whereas Bruck's meta-analytic average correlation is slightly stronger, -0.28 . Netemeyer and colleagues confirmed this significant negative correlation on three samples, with correlations of $0.36,-0.21$, and -0.27 (Netemeyer et al., 1996). Meta-analytic results show similar strengths of relationship: -0.23 (Allen et al., 2000) and -0.27 (Kossek \& Ozeki, 1999). Work-family conflict negatively impacts affective organizational commitment, defined as emotional attachment and involvement in the organization. It consists of identification with the employing organization and appreciation of the values that guide its policies and actions (Thompson et al., 1999; Netemeyer et al., 1996).

Negative spillover from work to family causes changes in attitudes that are non-work related. Particularly an individual, who frequently experiences problems in juggling multiple roles, tends to change attitudes about his/her family and life in general. The higher the work-family conflict, the lower the satisfaction with life (Kinnunen \& Mauno, 1998; Wayne et al., 2004; Netemeyer et al., 1996; Rupert et al., 2012). Netemeyer and colleagues confirmed a significant negative correlation on three samples with correlation coefficients as follows: $-0.33,-0.41$, and -0.53 (Netemeyer et al., 1996). The average weighted mean correlation in two meta-analyses was -0.31 ( -0.32 for women and -0.26 for men) (Kossek \& Ozeki, 1998) and -0.28 (Allen et al., 2000). Specifically, increased workfamily conflict causes family distress and decreases satisfaction with family (Aryee et al., 1999; Rupert et al., 2012). Basically, the rise of conflict decreases the quality of family life as it leads to family (parental) overload. Similarly, work-family conflict was negatively related to marital satisfaction in another study (Wu et al., 2010).

\subsection{Behavioral Outcomes}

The incapability of balancing work and family demands affects an individual's behavioral responses at the organizational level. On a daily basis, one faces the challenge of allocating limited resources to alternative domains. The consequences of experiencing conflict are particularly worrying in the organizations as they contribute to lower performance and ultimately firms' overall success (Arthur, 2003). There exists scarce evidence about the influence of conflict on work performance. Nevertheless, the findings show that conflict leads to adverse performance outcomes (van Steenbergen \& Ellemers, 2009). The results of meta-analytic studies report a negative relationship with the strength of -0.12 (Allen et al., 2000) and -0.03 (Kossek \& Ozeki, 1998). Turnover intention is another consequence that brings costs to the organization and is related to work-family interference. By leaving a job, a person conserves individual resources (time, energy) that would otherwise be lost from the stress caused in the work role (Grandey \& Cropanzano, 1999). Different studies report the positive influence of conflict on turnover intention (Barnett et al., 2004; Grandey \& Cropanzano, 1999; Anderson et al., 2002; Haar et al., 2012). Meta-analytic studies also confirm the positive nature of the relationship. In the Allen et al. (2000) study, turnover intention is, in fact, the variable, which is most strongly correlated with work-family conflict $(\rho=0.29)$ and even stronger is the correlation in another meta-analysis $(\rho=0.32)$ (Kossek \& Ozeki, 1998). The intensification of work-family conflict increases the probability of turnover in different professions, including academics (Grandey \& Cropanzano, 1999), public accountants (Greenhaus et al., 1997), as well as with small-company owners (Netemeyer et al., 1996). An interesting finding in one American study was that gender was found to be a significant predictor of turnover intention, with women being less likely to leave a job (Grandey \& Cropanzano, 1999). Greenhaus and colleagues found that workfamily conflict also leads to actual withdrawal from the company (Greenhaus et al., 1997).

The existing studies regarding absenteeism, as a consequence of conflicting role demands, show mixed results and different strengths of relationships. A meta-analytic study found practically a zero relationship with average mean correlation of -0.02 . It needs to be noted that it included only two studies (Allen et al., 2000). When the longitudinal relationship between work-family conflict and company records of absenteeism was studied, authors found that the bivariate relationship was insignificant. However, regression results did indicate a significant relationship once child-care facilities were implemented (Goff et al., 1990). A study of 432 employees found that women with a strong work-family conflict exhibit absenteeism, whereas they did not find this relationship among men. As it turned out, the relationship between perceived conflict and leaving early was stronger for employees with family responsibilities (Boyar \& Maertz, 2005). Apart from confirming the positive relationship between conflict and absenteeism, a recent longitudinal study found that participation in decision-making at work buffered this effect (Demerouti et al., 2011). 


\section{CONCLUDING REMARKS}

The intention of this paper was to adopt a holistic approach in studying the work-family conflict phenomenon by reviewing its most frequent antecedents and outcomes. The intensity of the perceived negative spillover from work to family has been steadily rising in the last couple of decades (Carlson et al., 2011; Michel et al., 2011). Thus, it is expected that due to the current economic, financial, and social crisis, work-family conflict will be even more prevalent in the years to come. One reason for this assumption lies in the evident longer working hours that are a consequence of the rising fear of job-loss and budget cuts. Another potential cause for concern is the fact that human resource (and other) departments have less financial resources for implementation of policies for reducing conflict between work and family.

Contributions of the paper are various. First, the paper focuses on one dimension of work-family conflict (only includes studies of work-family conflict), which enable a thorough investigation of its mediating role. Next, the paper systematically presents both antecedents and outcomes, which are examined from the individual perspective. Cause and effect variables are classified in five categories, which were chosen in accordance with the nature of variables. Third, among antecedents, a special emphasis is given to the examination of individual differences, a relatively new research stream within the work-family area. Limitations to the present review should be noted. First, focusing on conflict caused by work domain, the review does not include information regarding family-work conflict and its particular antecedents and outcomes. Second, findings based on the trichotomization of time-, strain-, and behavior-based conflict (particularly the latter, which is rarely examined in the work-home literature) are not evaluated, as the majority of studies evaluate work-family conflict without specifying its form. Literature assumes that the most prevalent conflict is time-based. In some instances (where the authors used measures of different forms of conflict), the differences in strength of relationships are reported. Third, the review does not include other types of work-family dynamics like those that investigate the positive spillover from work to family.

In terms of practical implications of the review, it is crucial to note that interest groups (individuals, managers, and policy-makers) should not view the work-family conflict as an individual responsibility, but rather as a problem that needs to be addressed at all levels of society. It is of great importance to understand which variables cause work-family conflict and what are its most frequent and detrimental consequences so that individual, organizational, and public initiatives can strive to reduce the conflict. Namely, it is only by recognizing the problem through its symptoms that effective solutions can be developed. Additionally, this review of the literature confirms the claim that apart from situational variables, dispositional variables and values influence the perception of workfamily conflict. With this, it raises awareness about the unique experience of the conflict within the individual that is not the consequence of solely situational factors.

\section{AUTHOR INFORMATION}

Katarina Katja Mihelič is an Assistant Professor at the Department of Management and Organization at the Faculty of Economics, University of Ljubljana. She received her $\mathrm{PhD}$ in business administration and organization. Her research is in the area of work-family dynamics, ethical behaviour and individual determinants of different behavioural outcomes. She regularly attends international conferences and publishes manuscripts in different journals. E-mail: katja.mihelic@ef.uni-lj.si (Corresponding author)

Metka Tekavčič is a professor at the Department of Management and Organization at the Faculty of Economics, University of Ljubljana. She is the Director of the Institute of Management and Organisation and was recently appointed Dean of Faculty of Economics, University of Ljubljana. Her research interests are in cost management and performance measurement. She has attended many international conferences, where she has presented papers in her research area and has published different articles in European and U.S. journals. She is a member of editorial boards in several journals from her research field. E-mail: metka.tekavcic@ef.uni-lj.si 


\section{REFERENCES}

1. Allard, K., Haas, L., \& Hwang, C. (2011). Family-Supportive organizational culture and fathers' experiences of work-Family conflict in Sweden. Gender, Work \& Organization, 18(2), 141-157.

2. Allen, T. D., Herst, D. E., Bruck, C. S., \& Sutton, M. (2000). Consequences associated with work-to-family conflict: A review and agenda for future research. Journal of Occupational Health Psychology, 5(2), 278308.

3. Anderson, S. E., Coffey, B. S., \& Byerly, R. T. (2002). Formal organizational initiatives and informal workplace practices: Links to work-family conflict and job-related outcomes. Journal of Management, 28(6), 787-810.

4. Andreassi, J. K. (2011). What the Person brings to the table personality, coping, and work-family conflict. Journal of Family Issues, 32(11), 1474-1499.

5. Arthur, M. M. (2003). Share price reactions to work-family initiatives: An institutional perspective. Academy of Management Journal, 46(4), 497-505.

6. Aryee, S., Luk, V., Leung, A., \& Lo, S. (1999). Role Stressors, interrole conflict, and well-being: The Moderating influence of spousal support and coping behaviors among employed parents in Hong Kong. Journal of Vocational Behavior, 54(2), 259-278.

7. Baltes, B. B., Zhdanova, L. S., \& Clark, M. A. (2011). Examining the Relationships between personality, coping strategies, and work-family conflict. Journal of Business and Psychology, 26(4), 517-530.

8. Barnett, R. C., Gordon, J. R., Gareis, K. C., \& Morgan, C. (2004). Unintended consequences of job redesign. Community, Work \& Family, 7(2), 227-246.

9. Beauregard, T. A. (2006). Predicting interference between work and home: A comparison of dispositional and situational antecedents. Journal of managerial Psychology, 21(3), 244-264.

10. Bellavia, G. M., \& Frone, M. R. (2005). Work-family conflict. In J. Barling, E. K. Kelloway, \& M. R. Frone (Eds.) Handbook of work stress (pp. 113-147). London: Sage.

11. Benligiray, S., \& Sönmez, H. (2012). Analysis of organizational commitment and work-family conflict in view of doctors and nurses. The International Journal of Human Resource Management, 23(18), 38903905.

12. Biggart, L., Corr, P., O’Brien, M., \& Cooper, N. (2010). Trait emotional intelligence and work-family conflict in fathers. Personality and individual Differences, 48(8), 911-916.

13. Blanch, A., \& Aluja, A. (2012a). Social support (family and supervisor), work-family conflict, and burnout: Sex differences. Human Relations, 65(7), 811-833.

14. Blanch, A., \& Aluja, A. (2012b). Social support (family and supervisor), work-family conflict, and burnout: Sex differences. Human Relations, 65(7), 811-833.

15. Bolino, M. C., \& Turnley, W. H. (2005). The personal costs of citizenship behavior: The relationship between individual initiative and role overload, job stress, and work-family conflict. Journal of Applied Psychology, 90(4), 740.

16. Boyar, S., \& Maertz, C. (2005). The effects of work-family conflict and family-work conflict on nonattendance behaviors. Journal of Business Research, 58(7), 919-925.

17. Bruck, C. S., \& Allen, T. D. (2003). The relationship between big five personality traits, negative affectivity, type A behavior, and work-family conflict. Journal of Vocational Behavior, 63(3), 457-472.

18. Bruck, C. S., Allen, T. D., \& Spector, P. E. (2002). The Relation between work-family conflict and job satisfaction: A finer-grained analysis. Journal of Vocational Behavior, 60(3), 336-353.

19. Byron, K. (2005). A meta-analytic review of work-family conflict and its antecedents. Journal of Vocational Behavior, 67(2), 169-198.

20. Carlson, D. S. (1999). Personality and Role variables as predictors of three forms of work-family conflict", Journal of Vocational Behavior, 55(2), 236-253.

21. Carlson, D. S., Ferguson, M., Hunter, E., \& Whitten, D. (2012). Abusive supervision and work-family conflict: The path through emotional labor and burnout. The Leadership Quarterly.

22. Carlson, D. S., Grzywacz, J. G., Ferguson, M., Hunter, E. M., Clinch, C. R., \& Arcury, T. A. (2011). Health and turnover of working mothers after childbirth via the work-family interface: An analysis across time. Journal of Applied Psychology, 96(5), 1045-1054. 
23. Casper, W. J., Harris, C., Taylor-Bianco, A., \& Wayne, J. H. (2011). Work-family conflict, perceived supervisor support and organizational commitment among Brazilian professionals. Journal of Vocational Behavior, 79(3), 640-652.

24. Cinamon, R. G. (2006). Anticipated work-family conflict: Effects of gender, self-efficacy, and family background. Career Development Quarterly, 54(3), 202-215.

25. de Luis Carnicer, M., Sánchez, A., Pérez, M., \& Jiménez, M. (2004). Work-family conflict in a southern European country: The influence of job-related and non-related factors. Journal of Managerial Psychology, 19(5), 466-489.

26. Demerouti, E., Bouwman, K., \& Sanz-Vergel, A. I. (2011). Job resources buffer the impact of work-family conflict on absenteeism in female employees. Journal of Personnel Psychology, 10(4), 166.

27. Dugan, A. G., Matthews, R. A., \& Barnes-Farrell, J. L. (2012). Understanding the roles of subjective and objective aspects of time in the work-family interface. Community, Work \& Family, 15(2), 149-172.

28. Duxbury, L. E., \& Higgins, C. A. (2002). Work-life Balance in the new millennium where are we? Where do we need to go? Ottawa, Canadian Policy Research Networks pp. 1-95.

29. Eby, L. T., Casper, W. J., Lockwood, A., Bordeaux, C., \& Brinley, A. (2005). Work and family research in IO/OB: Content analysis and review of the literature (1980-2002). Journal of Vocational Behavior, 66(1), 124-197.

30. Frone, M. R. (2000). Work-family conflict and employee psychiatric disorders: The National Comorbidity survey. Journal of Applied Psychology, 85(6), 888-95.

31. Frone, M. R., Russell, M., \& Cooper, M. L. (1992). Prevalence of work-family conflict: Are work and family boundaries asymmetrically permeable? Journal of Organizational Behavior, 13(7), 723-729.

32. Frone, M. R., Russell, M., \& Cooper, M. L. (1997). Relation of work-family conflict to health outcomes: A four-year longitudinal study of employed parents. Journal of Occupational and Organizational Psychology, 70(4), 325-335.

33. Geurts, S., Rutte, C., \& Peeters, M. (1999). Antecedents and consequences of work/home interference among medical residents. Social Science \& Medicine, 48(9), 1135-1148.

34. Goff, S. J., Mount, M. K., \& Jamison, R. L. (1990). Employer supported child care, work/family conflict and absenteeism: A field study. Personnel Psychology, 43(4), 793-809.

35. Grandey, A. A., \& Cropanzano, R. (1999). The Conservation of resources model applied to work-family conflict and strain. Journal of Vocational Behavior, 54(2), 350-370.

36. Grant-Vallone, E. J., \& Donaldson, S. I. (2001). Consequences of work-family conflict on employee wellbeing over time. Work \& Stress, 15(3), 214-226.

37. Greenhaus, J. H., \& Beutell, N. J. (1985). Sources of conflict between work and family roles. Academy of Management Review, 10(1), 76-88.

38. Greenhaus, J. H., Collins, K. M., Singh, R., \& Parasuraman, S. (1997). Work and family influences on departure from public accounting. Journal of Vocational Behavior, 50(2), 249-270.

39. Grzywacz, J. G. (2000). Work-family spillover and health during midlife: Is managing conflict everything? American Journal of Health Promotion, 14(41), 236-2.

40. Grzywacz, J. G., Almeida, D. M., \& McDonald, D. A. (2002). Work-family spillover and daily reports of work and family stress in the adult labor force. Family Relations, 51(1), 28-36.

41. Grzywacz, J. G., \& Marks, N. F. (2000). Reconceptualizing the work-family interface: An ecological perspective on the correlates of positive and negative spillover between work and family. Journal of Occupational Health Psychology, 5(1), 111-126.

42. Haar, J. M., Roche, M., \& Taylor, D. (2012). Work-family conflict and turnover intentions of indigenous employees: The importance of the whanau/family for Maori. The International Journal of Human Resource Management, 23(12), 2546-2560.

43. Halbesleben, J. R. B., Wheeler, A. R., \& Rossi, A. M. (2012). The costs and benefits of working with one's spouse: A two-sample examination of spousal support, work-family conflict, and emotional exhaustion in work-linked relationships. Journal of Organizational Behavior, 33(5), 597-615.

44. Innstrand, S. T., Langballe, E. M., Espnes, G. A., Aasland, O., \& Falkum, E. (2010a). Personal vulnerability and work-home interaction: The effect of job performance-based self-esteem on work/home conflict and facilitation. Scandinavian Journal of Psychology, 51(6), 480-487. 
45. Innstrand, S. T., Langballe, E. M., Espnes, G. A., Gjerl, O., \& Falkum, E. (2010b). Work-home conflict and facilitation across four different family structures in Norway. Community, Work \& Family, 13(2), 231249.

46. Kelly, E. L., Moen, P., \& Tranby, E. (2011). Changing workplaces to reduce work-family conflict. American Sociological Review, 76(2), 265-290.

47. Kinnunen, U., \& Mauno, S. (1998). Antecedents and outcomes of work-family conflict among employed women and men in Finnland. Human Relations, 51(2), 157-177.

48. Kossek, E. E., \& Ozeki, C. (1998). Work-family conflict, policies, and the job-life satisfaction relationship: A review and directions for organizational behavior-human resources research. Journal of Applied Psychology, 83(2), 139-149.

49. Kossek, E. E., \& Ozeki, C. (1999). Bridging the work-family policy and productivity gap: A literature review. Community, Work and Family, 2(1), 7-32.

50. Lapierre, L. M., Spector, P. E., Allen, T. D., Poelmans, S., Cooper, C. L., O'Driscoll, M. P., Sanchez, J. I., Brough, P., \& Kinnunen, U. (2008). Family-supportive organization perceptions, multiple dimensions of work-family conflict, and employee satisfaction: A test of model across five samples. Journal of Vocational Behavior, 73(1), 92-106.

51. Mauno, S., Kinnunen, U., \& Rantanen, M. (2011). Work-family conflict and enrichment and perceived health: Does type of family matter? Family Science, 2(1), 1-12.

52. Michel, J. S., \& Clark, M. A. (2009). Has it been affect all along? A test of work-to-family and family-towork models of conflict, enrichment, and satisfaction. Personality and individual Differences, 47(3), 163168 .

53. Michel, J. S., Kotrba, L. M., Mitchelson, J. K., Clark, M. A., \& Baltes, B. B. (2011). Antecedents of workfamily conflict: A meta-analytic review. Journal of Organizational Behavior, 32(5), 689-725.

54. Milliken, F. J. (2004). Time compressions at work: Implications for managing the work-life boundary. In E. E. Kossek (ed.). Putting work in its place: New perspectives on the working time of professionals. Academy of Management Symposium 2004.

55. Milliken, F. J., \& Dunn-Jensen, L. M. (2005). The changing time demands of managerial and professional work: Implications for managing the work-life boundary. In E. E. Kossek \& S. J. Lambert (Eds.) Work and Life Integration: Organizational, Cultural, and Individual Perspectives (pp. 43-60). New Jersey: Lawrence Erlbaum Associates.

56. Netemeyer, R. G., Boles, J. S., \& McMurrian, R. (1996). Development and validation of work-family conflict and family-work conflict scales. Journal of Applied Psychology, 81(4), 400-410.

57. Ng, T. W. H., \& Feldman, D. C. (2008). Long work hours: A social identity perspective on meta analysis data. Journal of Organizational Behavior, 29(7), 853-880.

58. Noor, N. M. (2002). Work-family conflict, locus of control, and women's weil-being: Tests of alternative pathways. The Journal of Social Psychology, 142(5), 645-662.

59. Peeters, M., Waltez, C., Demerouti, E., \& de Regt, W. (2009). Work-family culture, work-family interference and well-being at work. Is it possible to distinguish between a positive and a negative process? Career Development International, 14(6-7), 700-713.

60. Premeaux, S. F., Adkins, C. L., \& Mossholder, K. W. (2007). Balancing work and family: A field study of multi-dimensional, multi-role work-family conflict. Journal of Organizational behavior, 28(6), 705.

61. Rantanen, J., Pulkkinen, L., \& Kinnunen, U. (2005). The Big Five personality dimensions, work-family conflict, and psychological distress: A longitudinal view. Journal of Individual Differences, 26(3), $155-166$.

62. Rupert, P. A., Stevanovic, P., Hartman, E. R. T., Bryant, F. B., \& Miller, A. (2012). Predicting workfamily conflict and life satisfaction among professional psychologists. Professional Psychology: Research and Practice, 43(4), 341.

63. Stoeva, A. Z., Chiu, R. K., \& Greenhaus, J. H. (2002). Negative affectivity, role stress, and work-family conflict. Journal of Vocational Behavior, 60(1), 1-16.

64. Sumer, H. C., \& Knight, P. A. (2001). How do people with different attachment styles balance work and family? A personality perspective on work-family linkage. Journal of Applied Psychology, 86(4), 653-663.

65. Thomas, L. T., \& Ganster, D. C. (1995). Impact of family-supportive work variables on work-family conflict and strain: A control perspective. Journal of Applied Psychology, 80(1), 6-15. 
66. Thompson, C. A., Beauvais, L. L., \& Lyness, K. S. (1999). When work-family benefits are not enough: the influence of work-family culture on benefit utilization, organizational attachment, and work-family conflict. Journal of Vocational Behavior, 54(3), 392-415.

67. Valcour, M., Ollier-Malaterre, A., Matz-Costa, C., Pitt-Catsouphes, M., \& Brown, M. (2011). Influences on employee perceptions of organizational work-life support: Signals and resources. Journal of Vocational Behavior, 79(2), 588-595.

68. van Steenbergen, E. F., \& Ellemers, N. (2009). Is managing the work-family interface worthwhile? Benefits for employee health and performance. Journal of Organizational Behavior, 30(5), 617-642.

69. Voydanoff, P. (2007), Work, family, and community: Exploring interconnections. Lawrence Erlbaum Associates, Mahwah.

70. Wayne, J. H., Musisca, N., \& Fleeson, W. (2004). Considering the role of personality in the work-family experience: Relationships of the big five to work-family conflict and facilitation. Journal of Vocational Behavior, 64(1), 108-130.

71. Winslow, S. (2005). Work-Family Conflict, Gender, and Parenthood, 1977-1997. Journal of Family Issues, 26(6), 727-755.

72. Wu, M., Chang, C.-C., \& Zhuang, W.-L. (2010). Relationship of work-family conflict with business and marriage outcomes in Taiwanese copreneurial women. The International Journal of Human Resource Management, 21(5), 742-753. 


\section{NOTES}

